\title{
Trophic ecology of the freshwater prawn, Pseudopalaemon bouvieri (Decapoda: Palaemonidae) in Northeastern Argentina, with remarks on population structure
}

\author{
Romina Patricia Carnevali ${ }^{1,2}$, Pablo Agustín Collins ${ }^{3,4}$ \& Alicia S. Guadalupe Poi de Neiff ${ }^{1,2}$ \\ 1. Centro de Ecología Aplicada del Litoral (CECOAL-CONICET), Ruta 5 km. 2.5, C. C. 291, Corrientes, Argentina; \\ romicarnevali@gmail.com \\ 2. Departamento de Biología, Universidad Nacional del Nordeste (UNNE). 3400, Corrientes, Argentina; \\ guadalupepoi@gmail.com \\ 3. Instituto Nacional de Limnología. Facultad de Bioquímica y Ciencias Biológicas (INALI-CONICET-UNL). 3016. \\ Santa Fe, Argentina; pagcollins@gmail.com \\ 4. Facultad de Ciencias y Tecnología (UADER), Paraná, Entre Ríos, Argentina.
}

Received 27-IV-2011. Corrected 09-VIII-2011. Accepted 08-IX-2011.

\begin{abstract}
Freshwater decapod crustaceans are important components of food webs in these environments, but little is known about the diet of species that live in tropical waters. We studied the feeding ecology of the prawn Pseudopalaemon bouvieri and its population structure in two different areas with six lagoons, with a different composition and abundance of aquatic macrophytes. At each site of macrophytes banks, 18 prawns sample was collected with a hand net ( $1 \mathrm{~mm}$ mesh size) from $1 \mathrm{~m}^{2}$. In the laboratory, prawns cephalothorax length was measured, sex determined, and a total of 208 stomachs were examined for food items. Our results showed that the population abundance varied between $10 \mathrm{ind} / \mathrm{m}^{2}$ and $1411 \mathrm{ind} / \mathrm{m}^{2}$. The cephalothorax length ranged between $6 \mathrm{~mm}$ and $21 \mathrm{~mm}$, and the male:female ratio varied between 0.3 and 1.0 , with a higher proportion of ovigerous females $(21 \%)$ in area one than area two. P. bouvieri is omnivorous, and its diet was principally based on algae, plant remains, Protozoa, Rotifera, Oligochaeta, Crustacea, Insecta, detritus and other items. The analysis of the stomach content did not reveal any significant difference in the diet between juveniles and adults, and males and females of both areas consumed a similar diet (Kruskal-Wallis test $\mathrm{p}=0.8273$ ). We concluded that the dietary items consumed by prawns and the niche breadth were similar between the two areas, although the proportion of items consumed varied between lagoons of both areas. The density of P. bouvieri was different between areas, but the size of cephalothorax (CL) was similar. Rev. Biol. Trop. 60 (1): 305-316. Epub 2012 March 01.
\end{abstract}

Key words: feeding ecology, omnivorous, sex ratio, prawn densities, Crustacea.

Decapod crustaceans are important components of food webs in freshwater environments, and for many years they were considered to have detritivorous and necrofagous habits. However, several research studies have shown that these organisms can capture live animals in an active action, and are present in different habitats such as aquatic plants, the water column or benthic communities (Collins 1997, Collins \& Paggi 1998, Jayachandra 2001, Collins et al. 2004, Collins et al. 2006). Other studies have suggested that prawns are essentially omnivorous
(Walker 2009) and have an important role as shredders in tropical waters (Rosemond et al. 1998). In addition, numerous studies have indicated that the freshwater prawns and crabs are important components of the diets of fishes, reptiles, birds and mammals (Collins et al. 2006, Borteiro et al. 2009).

Pseudopalaemon bouvieri Sollaud 1911 lives in hipoosmotic environments with distribution in Southern Brazil, Northeastern Argentina and Eastern Uruguay (Bond-Buckup \& Buckup 1989). In Argentina, it is restricted to 
the water bodies of Corrientes and Entre Ríos (Lopretto 1995), at the Paraná and Uruguay River basins. In these systems, the species of Palaemonidae inhabits in swamps, shallow ponds, lagoons, streams and rivers, some of which are characterized by very low salinity (Poi de Neiff 2003). In subtropical wetlands, the aquatic vegetation provides habitat of high complexity that structured the invertebrate assemblages (Poi de Neiff \& Neiff 2006, Thomaz et al. 2008). P. bouvieri diet has not been studied but Walker (2009) mentioned the feeding habits of other species of Pseudopalaemon. In the present study, we compared the feeding ecology of the freshwater prawn $P$. bouvieri, in lagoons having a different composition and abundance of aquatic macrophytes. Moreover, differences in abundance, sex ratio, proportion of ovigerous females and prawn size were also considered. We investigated the hypothesis that the feeding ecology of $P$. bouvieri and its population structure differ in lagoons with different biotic and abiotic characteristics.

\section{MATERIALS AND METHODS}

Study site: We selected six lagoons (Fig. 1) located near to the Paraná River (area 1) and the Uruguay River (area 2), each with a similar depth, a small area, sand-fine sediments and a variable composition of aquatic plants. Changes in volume depended mainly on the rainwater in area 1 , which primarily produces input water with very low dissolved salt content. Because, the left bank of the Paraná River and the right bank of Uruguay River are high, the lagoons are not located in the floodplain of both rivers.

Field procedures: Water temperature, dissolved oxygen, conductivity, and $\mathrm{pH}$ were measured simultaneously on each sampling occasion with digital equipment (Chekmate 90 Corning; Oxi-30 WTW; 330 WTW). Transparency was estimated using a Secchi disc.

Prawns were collected in the morning, during spring, using a hand net $\left(900 \mathrm{~cm}^{2}\right.$ diameter) with a $1 \mathrm{~mm}$ mesh size. Because, this time period was during the reproductive season, the

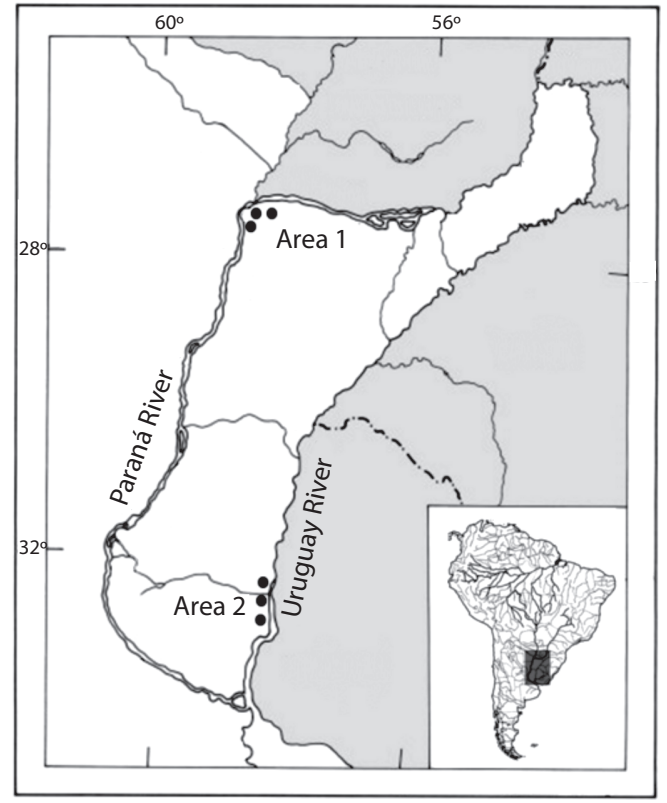

Fig. 1. Study area at the Northeastern Argentina with approximated location of the six shallow lakes used as sampling sites to feeding evaluation of Pseudopalaemon bouvieri at Paraná River (area 1) and the Uruguay River (area 2).

population density was high and all stages of $P$. bouvieri were present. At each site, 18 samples, covering each one an area of approximately $1 \mathrm{~m}^{2}$ following the macrophytes banks, were collected. Prawns were immediately anaesthetized by cooling in a refrigerator with ice and preserved in $10 \%$ buffered formalin in the field.

Laboratory procedures: Specimens of $P$. bouvieri were separated, and the sex was determined by appendix masculina (Boschi 1981). The cephalothorax length (CL) was measured using a caliper $( \pm 0.1 \mathrm{~mm})$, and the digestive tracts were removed under a stereoscopic microscope. Stomach fullness was estimated visually according to a subjective scale from 0 (empty) to 5 (full) (Collins \& Paggi 1998).

In order to compare food items, prawns in the intermolt (C) stage were used in all sampling sites and the minimum number of stomachs was defined. Stomach contents were mounted in $50 \%$ glycerol. Consumed items 
were sorted into taxonomic groups, counted, and measured under a compound microscope at $150 \mathrm{x}$ to $600 \mathrm{x}$. We examined 208 stomachs in total for both areas.

The gut content was assigned to 13 dietary items: unicellular algae, filamentous algae, fungi, macrophyte remains, Protozoa, Rotifera, Cladocera, Copepoda, Insecta larvae, Chironomidae larvae, Oligochaeta, Acaridae, and others (Porifera, Arachnidae). The different taxonomic groups were identified to the lowest possible taxonomic level using keys in Lopretto \& Tell 1995, Fernández \& Domínguez 2001, Zalocar de Domitrovic 2003.

Prawn densities and limnological parameters were compared between lagoons from both areas using the Kruskal-Wallis test and the post test of Mann-Whitney pairwise comparisons. The minimum number of stomachs was determined using the mean cumulative trophic diversity based on ICE mean, Bootstrap and Chao I indexes according to the EstimateS Win 8.00 program (Colwell 2006) (Fig. 2). The comparison of prawn size and density was assessed by one way analysis-of-variance (ANOVA). Differences were tested using a Tukey HSD post-test according to Zar (1996).

Standard methods were employed for the evaluation of variation in feeding intensity involving the determination of the fullness index, which was calculated according to the expression $\mathrm{FI}=(\mathrm{NSFS} / \mathrm{NT}) * 100$, where NSFS is the number of stomachs at each fullness scale, and NT is the total number of stomachs. The fullness index homogeneity among sites was compared with a $\mathrm{Chi}^{2}$ test. To establish the importance of each fullness scale, food volumes were calculated by approximation to regular geometric shapes or converted to volume data for weight according to the literature (Edmonson \& Winberg 1971, Dumont et al. 1975, Ruttner-Kolisko 1977).

Niche breadth was estimated for each sampled area using the equation of Ricklefs (1979),

$$
B=\left(\sum_{i=1}^{n} p i^{2}\right)^{-1}
$$
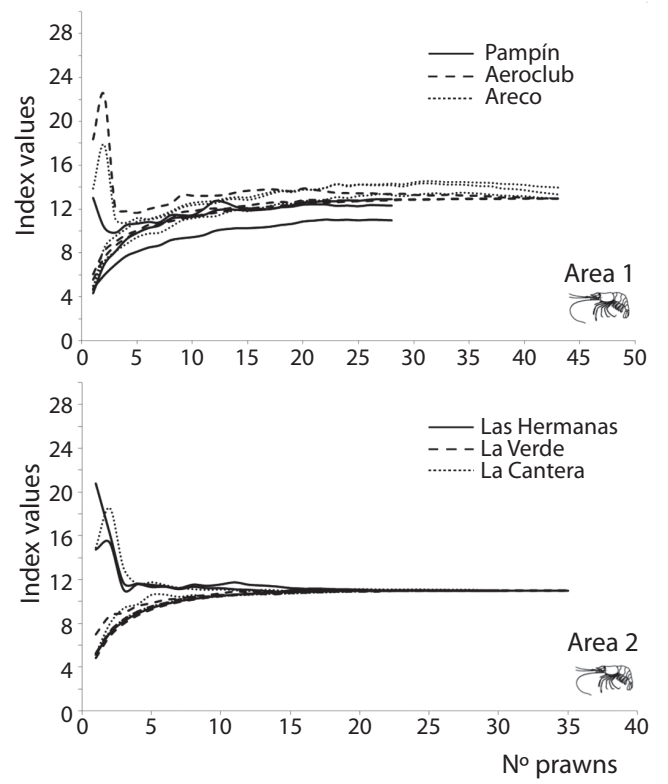

Fig. 2. Cumulative trophic diversity based on ICE mean, Bootstrap and Chao I indexes for the freshwater prawn Pseudopalaemon bouvieri collected from three shallow lakes near to Paraná River and Uruguay River.

where $p i$ is the proportion of individuals found using resource i. Values of niche breadths were standardized on a scale of zero to one (Pianka 1973).

The food items were analyzed by means of the Index of Relative Importance (Pinkas et al. 1971), IRI $=\left(C_{v}+C_{n}\right) * F_{o}$, where $C_{v}$ is the volumetric content of the prey, $C_{n}$ is the numeric content of the prey, and $F_{o}$ is the frequency of the occurrence of a prey item. The variation coefficient of the IRI for each item was performed for both areas.

To assess the main contribution (volume or frequency) of the prey, we used the Weighted Result Index, $\mathrm{R}_{\mathrm{w}}=\left[\left[Q\left(v_{i}{ }^{2}+o_{i}\right)^{1 / 2}\right] *\left[\Phi Q\left(v_{i}{ }^{2}+\right.\right.\right.$ $\left.\left.\left.o_{i}^{2}\right)^{1 / 2}\right]^{-1}\right]^{*} 100$, where $v$ is a volume percentage of item ${ }_{1}, O$ is an occurrence percentage of item ${ }_{1}, Q$ takes into account the deviation of angle $\Phi$ from the mid-way, while grading the importance of the food. The angle is determined as $\tan ^{-1}\left(o_{i} / v_{i}\right)$ (Mohan \& Sankaran 1988, Williner 2010). 


\section{RESULTS}

Temperature and $\mathrm{pH}$ (Table 1) were not statistically significant different between areas 1 and $2\left(\mathrm{~K}_{-}-\mathrm{W}_{\text {temperature }}: 10.3, \mathrm{p}=0.0675 ; \mathrm{K}-\mathrm{W}_{\mathrm{pH}}\right.$ : $10.12, \mathrm{p}=0.0718)$. The water was mostly transparent in area $1(\mathrm{~K}-\mathrm{W}: 14.3, \mathrm{p}=0.0117)$ and had more electrical conductivity in area 2 (K-W: 17.3, $\mathrm{p}=0.0039)$. The concentration of dissolved oxygen did not differ between areas (K-W: 4.59, $\mathrm{p}=0.322$ ), but it was highest in two lagoons of area $1(\mathrm{~K}-\mathrm{W}: 9.06, \mathrm{p}=0.0108)$.

The composition and abundance of vegetation was dissimilar in both areas, with submerged aquatic plants (mainly Egeria densa Planch.) dominating in area 1 and flooded green grass and Nymphoides indica (L.) Kuntze dominated in area 2 (Table 1).

The density of prawns varied between $10 \mathrm{ind} / \mathrm{m}^{2}$ and $1411 \mathrm{ind} / \mathrm{m}^{2}$, being statistically significant different between areas ( $\mathrm{F}$ : 8.77, $\mathrm{p}=0.01$ ). Mean values (Table 1) were similar in area $2(\mathrm{~K}-\mathrm{W}: 3.82, \mathrm{p}=0.1479)$ and statistically significant different in one lagoon of area 1 respect to other lagoons of this zone (K-W: 7.01, $\mathrm{p}=0.0302)$. The size of $\mathrm{CL}$ ranged between $6 \mathrm{~mm}$ and $21 \mathrm{~mm}$ (Fig. 3), being similar in both areas (F: 1.09, p=0.733), and the male:female ratio varied between 0.3 and 1.0 with a higher proportion of ovigerous females $(21 \%)$ in area 1 when compared to area 2 . When the vegetation was scarce in the lagoons, males and females were found in similar proportions.

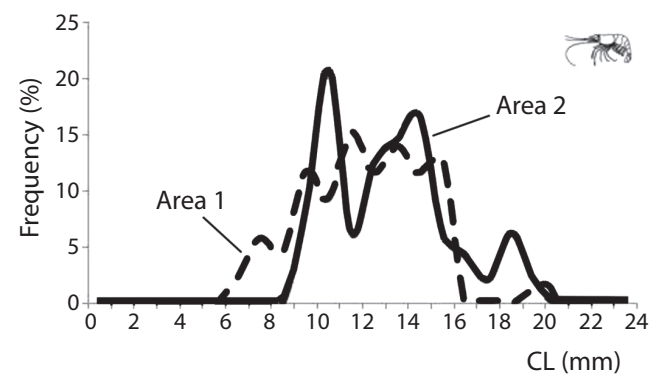

Fig. 3. Frequency of the prawn size Pseudopalaemon bouvieri collected in the environments near to Paraná River (area 1) and the Uruguay River (area 2) used in the feeding analysis of the prawns.

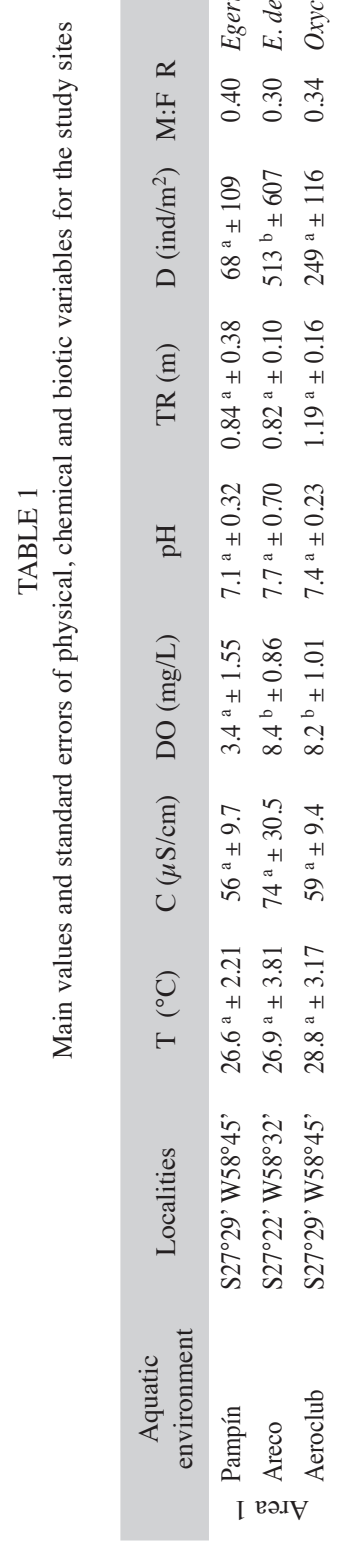


In the study sites, stomach fullness varied between 0 and 5 , with a mean of $3.23 \pm 1.22$, and, with a very low number of empty stomachs $(15 \%)$. We found that more than $60 \%$ of the prawns had stomach fullness (Fig. 4) in the 3, 4 and 5 scale (level medium and full). However the percentage of each fullness scale was different between both zones $\left(\mathrm{Chi}^{2}: 12.99\right.$, $\mathrm{p}=0.0113$ ). The minimum number of stomachs was estimated in 13 and 11 for areas 1 and 2, respectively (Fig. 2). The highest number of stomachs was found in lagoons with a high abundance of aquatic vegetation (area 1).

The principal food resources recorded in both areas are listed in table 2 . The consumed items consisting of planktonic, benthonic or others organisms associated to aquatic plants.

The more abundant algaes were Staurastrum sp., Staurodesmus sp., Dinobryon sp., Oedogonium sp., Basicladia sp. and Scenedesmus sp. Rotifers, Lecane sp. and Keratella sp., were more abundant in area 2. Other registered items were Cladocera (mainly Iliocryptus sp., Bosmina sp., and Chydorus sp.) as well as
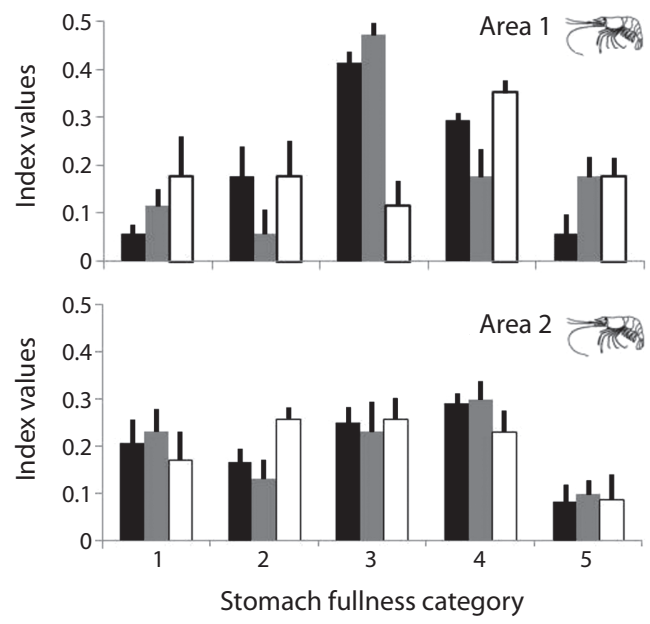

Fig. 4. Mean frequency of stomach fullness (\%) in the prawn Pseudopalaemon bouvieri from samples at areas 1 and 2. Grade 1 and 2 (empty and low); 3, 4 and 5 (medium and full).

Bars: standard deviation. Paraná River (area 1: Areco (black), Pampín (gray) and Aeroclub (white) lagoons) and the Uruguay River (area 2: La Verde (black), Las Hermanas (gray) and La Cantera (white) lagoons).
Copepoda (Table 2). Insecta larvae (mainly Chironomidae, Parachironomus sp.), together with Oligochaeta (Table 2), displayed a larger volume and a higher frequency in area 2.

Males and females of both areas had similar ranges for the types of items consumed (K-W: $0.05, \mathrm{p}=0.8273$ ). However, these were unlike between areas (K-W: 6.56, $\mathrm{p}=0.0104)$. The trophic niche was alike among juveniles, sub-adults and adults in each lagoon $(\mathrm{K}-\mathrm{W}$ : 2.03, $\mathrm{p}=0.1573$ ).

The niche breadth of prawns from the six lagoons varied between 0.56 and 0.87 . The largest values were obtained in area 2 , with mean values of $0.84 \pm 0.036$; while in area 1 , this index had a mean value of $0.66 \pm 0.123$. The differences between areas were not statistically significant $(\mathrm{F}=7.22, \mathrm{p}=0.055)$.

Macrophytes remain and the algae items (Fig. 5) showed the greatest values for the importance relative index (IRI). Moreover, these values were higher for the stomach content from organisms in the lagoons of area 1 compared to area 2 (except for unicellular algae $)\left(\mathrm{K}-\mathrm{W}_{\text {macrophyte remains }}: 5.33, \mathrm{p}=0.0209\right.$; $\mathrm{K}-\mathrm{W}_{\text {filamentous algae }}: 4.08, \mathrm{p}=0.03 ; \mathrm{K}-\mathrm{W}_{\text {unicellular }}$ algae $: 0.01, \mathrm{p}=0.8852)$. The IRI values for the animal components were lower than those for the vegetal components, with Protozoa and Insecta larvae as more frequent in some lagoons of area $1\left(\mathrm{~K}-\mathrm{W}_{\text {protozoa }}: 5.5, \mathrm{p}=0.0339 ; \mathrm{K}-\mathrm{W}_{\text {insecta }}\right.$ larvae: $: 53, \mathrm{p}=0.0210)$, and Rotifera, Cladocera, Copepoda and Oligochaeta as more frequent

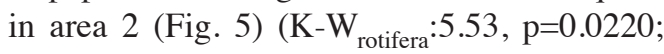
$\mathrm{K}-\mathrm{W}_{\text {cladocera }}: 5.33, \mathrm{p}=0.0271 ; \mathrm{K}-\mathrm{W}_{\text {copepoda }}: 4.91$, $\mathrm{p}=0.02952 ; \quad \mathrm{K}-\mathrm{W}_{\text {oligochaeta }}: 5.33, \quad \mathrm{p}=0.0209$ ). Whilst the Chironomidae larvae is consumed alike in both areas (K-W:0.01, $\mathrm{p}=0.8852$ ). The coefficient variations of the IRI were more stable in the lagoons with lower diversities and densities of aquatic vegetation (area 2). Moreover, the CV was higher for the animal items (Cladocera and Copepoda in area 1; Protozoa and Rotifera in area 2) (Fig. 5).

In the lagoons of the areas 1 and 2 there were a major proportion of Oligochaeta and Chironomidae larvae, when the volume was considered (RW index, Fig. 6) and other food 
TABLE 2

List of elements consumed by Pseudopalaemon bouvieri in the lagoons at both studied areas (1 and 2)

\begin{tabular}{|c|c|c|c|c|c|}
\hline & Area 1 & Area 2 & & Area 1 & Area 2 \\
\hline ALGAE & & & FUNGI & & \\
\hline Zygophyceae & & & Hifas & $\mathrm{X}$ & $\mathrm{X}$ \\
\hline Bambusina sp. & $X$ & & & & \\
\hline Closterium sp. & & $\mathrm{X}$ & PLANT REMAINS & $\mathrm{X}$ & $\mathrm{X}$ \\
\hline Cosmarium sp. & $X$ & $\mathrm{X}$ & & & \\
\hline Docidium sp. & $\mathrm{X}$ & & PROTOZOA & & \\
\hline Euastrum sp. & $X$ & & Arcella sp. & $\mathrm{X}$ & $\mathrm{X}$ \\
\hline Micrasterias sp. & $\mathrm{X}$ & $\mathrm{X}$ & Centropyxis sp. & $\mathrm{X}$ & \\
\hline Pleurodiscus sp. & $X$ & & & & \\
\hline Pleurotaenium sp. & $\mathrm{X}$ & $\mathrm{X}$ & ROTIFERA & & \\
\hline Sphaerosozma sp. & $X$ & & Brachionus sp. & & $\mathrm{X}$ \\
\hline Staurastrum sp. & $\mathrm{X}$ & $\mathrm{X}$ & Keratella sp. & $\mathrm{X}$ & $\mathrm{X}$ \\
\hline Staurodesmus sp. & $X$ & & Lecane sp. & $\mathrm{X}$ & $\mathrm{X}$ \\
\hline Xanthidium sp. & $\mathrm{X}$ & & Polyarthra sp. & & $\mathrm{X}$ \\
\hline \multirow[t]{2}{*}{ Zygnema sp. } & $\mathrm{X}$ & $X$ & & & \\
\hline & & & OLIGOCHAETA & $\mathrm{X}$ & $\mathrm{X}$ \\
\hline \multicolumn{6}{|l|}{ Euchlorophyceae } \\
\hline Ankistrodesmus sp. & $\mathrm{X}$ & $\mathrm{X}$ & CRUSTACEA & & \\
\hline Basicladia sp. & $\mathrm{X}$ & $\mathrm{X}$ & Copepoda & & \\
\hline Coelastrum sp. & & $\mathrm{X}$ & Cyclopiodea & $\mathrm{X}$ & \\
\hline Coenocystis sp. & $\mathrm{X}$ & & Calanoidea & & $\mathrm{X}$ \\
\hline Chlorococcum sp. & $\mathrm{X}$ & & Diaptomus sp. & & $\mathrm{X}$ \\
\hline Desmodesmus sp. & $\mathrm{X}$ & & Copepodits & & $\mathrm{X}$ \\
\hline Diplochloris sp. & $\mathrm{X}$ & & no-identified & $\mathrm{X}$ & $\mathrm{X}$ \\
\hline Monoraphydium sp. & $\mathrm{X}$ & & & & \\
\hline Oocystis sp. & $\mathrm{X}$ & & Cladocera & & \\
\hline Pediastrum sp. & $\mathrm{X}$ & $\mathrm{X}$ & Alona sp. & $\mathrm{X}$ & \\
\hline Polyedriopsis sp. & $\mathrm{X}$ & & Bosmina sp & & $\mathrm{X}$ \\
\hline Scenedesmus sp. & $\mathrm{X}$ & $\mathrm{X}$ & Chydorus sp. & & $\mathrm{X}$ \\
\hline Selenastrum sp. & $\mathrm{X}$ & $\mathrm{X}$ & Illiocryptus sp. & & $\mathrm{X}$ \\
\hline \multirow[t]{2}{*}{ Volvox sp. } & & $\mathrm{X}$ & Macrothrix sp. & & $\mathrm{X}$ \\
\hline & & & no-identified & $\mathrm{X}$ & $\mathrm{X}$ \\
\hline \multicolumn{6}{|l|}{ Ulothricophyceae } \\
\hline Bulbochaete sp. & $\mathrm{X}$ & $\mathrm{X}$ & Ostracoda & $\mathrm{X}$ & $\mathrm{X}$ \\
\hline Oedogonium sp. & $\mathrm{X}$ & $\mathrm{X}$ & & & \\
\hline \multirow[t]{2}{*}{ Ulothrix sp. } & $\mathrm{X}$ & $\mathrm{X}$ & INSECTA & & \\
\hline & & & Adults no-identified & $\mathrm{X}$ & $\mathrm{X}$ \\
\hline Bacillariophyceae & & & Larvae & $\mathrm{X}$ & \\
\hline Aulacoseira sp. & $\mathrm{X}$ & & Tricoptera & & $\mathrm{X}$ \\
\hline Cymbella sp. & $\mathrm{X}$ & & & & \\
\hline Fragilaria sp. & $\mathrm{X}$ & $\mathrm{X}$ & Plecoptera & $\mathrm{X}$ & $\mathrm{X}$ \\
\hline Gomphonema sp. & $\mathrm{X}$ & $\mathrm{X}$ & & & \\
\hline \multirow[t]{2}{*}{ Stauroneis sp. } & $\mathrm{X}$ & & Diptera & $\mathrm{X}$ & \\
\hline & & & Chironomidae & & \\
\hline
\end{tabular}


TABLE 2 (Continued)

List of elements consumed by Pseudopalaemon bouvieri in the lagoons at both studied areas (1 and 2)

\begin{tabular}{|c|c|c|c|c|c|}
\hline & Area 1 & Area 2 & & Area 1 & Area 2 \\
\hline Xantophyceae & & & Parachironomus sp. & & $\mathrm{X}$ \\
\hline Tetraedron sp. & $\mathrm{X}$ & $\mathrm{X}$ & Pseudoparachironomus sp. & & $\mathrm{X}$ \\
\hline \multirow[t]{2}{*}{ Tribonema sp. } & $\mathrm{X}$ & $\mathrm{X}$ & Tanypodinae & & $\mathrm{X}$ \\
\hline & & & Chironomidae unidentified & $\mathrm{X}$ & \\
\hline \multicolumn{6}{|l|}{ Chrysophyceae } \\
\hline Dinobryon sp. & $\mathrm{X}$ & & Ephemeroptera & $\mathrm{X}$ & $\mathrm{X}$ \\
\hline Euglenophyceae & & & ACARI & $\mathrm{X}$ & $\mathrm{X}$ \\
\hline \multirow[t]{2}{*}{ Phacus sp. } & $\mathrm{X}$ & $\mathrm{X}$ & & & \\
\hline & & & ARACHNIDA & & \\
\hline Cyanophyceae & & & Pisauridae & & $\mathrm{X}$ \\
\hline Anabaena sp. & $\mathrm{X}$ & $\mathrm{X}$ & & & \\
\hline Aphanizomenon sp. & $\mathrm{X}$ & & Sand clast & $\mathrm{X}$ & $\mathrm{X}$ \\
\hline Coelosphaerium sp. & $\mathrm{X}$ & & & & \\
\hline Gomphosphaeria sp. & $\mathrm{X}$ & & Detritus & $\mathrm{X}$ & $\mathrm{X}$ \\
\hline Microcystis sp. & $\mathrm{X}$ & $\mathrm{X}$ & & & \\
\hline Nostoc sp. & $\mathrm{X}$ & & Remains unidentified & $X$ & $\mathrm{X}$ \\
\hline
\end{tabular}
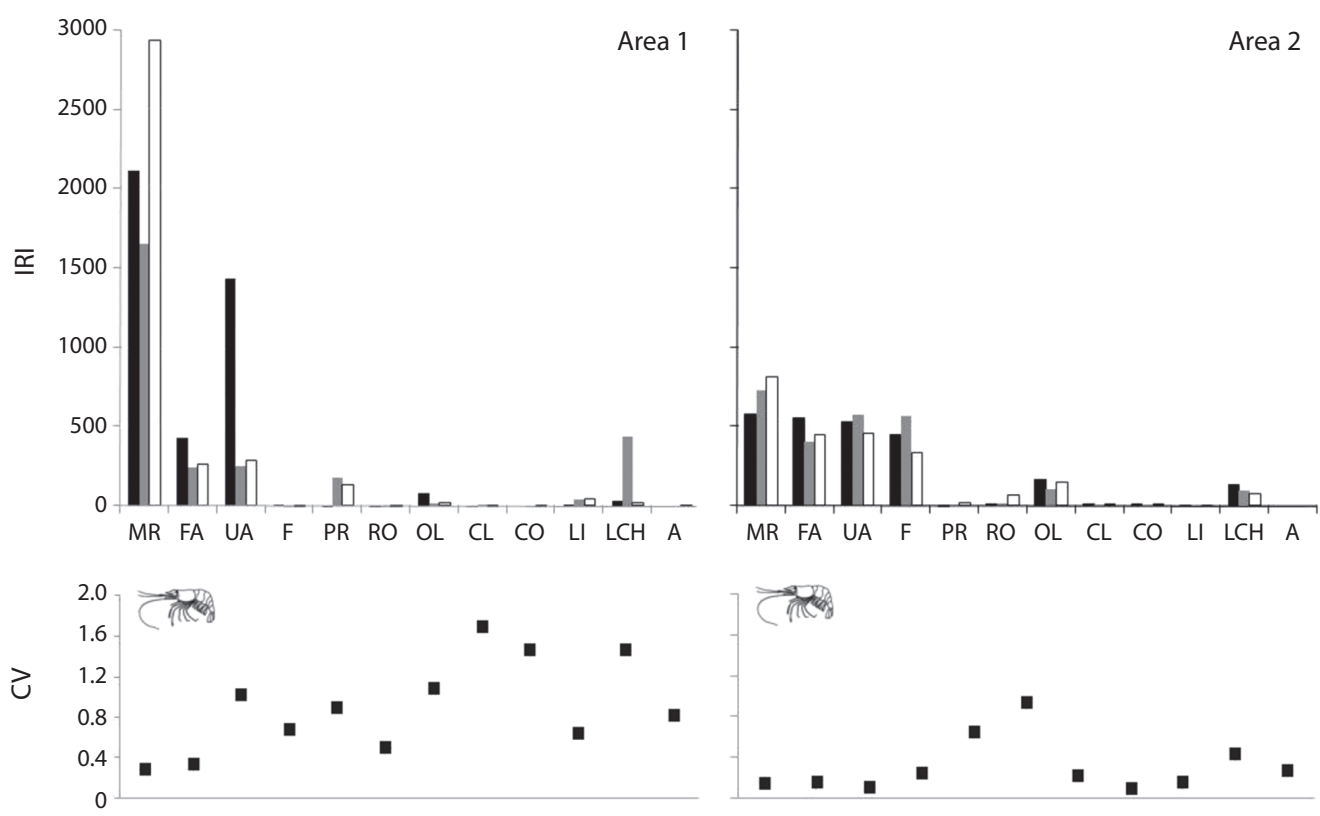

Fig. 5. Mean values for the Importance Relative Index (IRI) of the different food items of prawn Pseudopalaemon bouvieri for areas 1 and 2. MR, macrophytes remains; OL, oligochaetes; CO, copepods; CL, cladocerans; LCH, chironomidae larvae; LI, insects larvae; PR, protozoa; RO, rotifers; F, fungi; UA, unicellular algae; FA, filamentous algae; A, mite. CV: variation coefficient of each item for all samples sites at the two studied areas. 
items, when the frequency was considered. According to the RW index, the importance of each item varied with the numerical abundances (e.g., vegetal and some planktonic items) while among the animals, volume was more important (Fig. 6).

Moreover, other food resources that had a short life cycle (protozoa, rotifers, cladocerans and copepods), or for which the substratum type limit their development, displayed greater variation, while items more difficult to capture were those that have larger size and mobility (Ephemeroptera and Orthoptera larvae) (Collins 1995, Collins 1997, Collins et al. 2007).

\section{DISCUSSION}

The prawn P. bouvieri is omnivorous, consuming a wide spectrum of items, from algae that lives in plankton, benthos and pleuston, to insects. Many authors have shown that Palaemonidae species also have a diet made up of a number of different items, although detritus is usually an important and quite common component (Howard 1984, Collins \& Paggi 1998, Albertoni et al. 2003, Walker 2009). Not only does this group, but also those members of the Peneidae family present in estuarial environments, use the detritus (Masitah \& Chong 2002). In the same way, in freshwater crabs and anomurans are also present this source (Collins et al. 2007).

The minimum number of specimens, that permit the observation of the complete trophic spectrum used by the prawns was relatively low (11-13 stomach prawns). However, we used three to four times the minimum number. The low number needed for the observation proves the similarities in the trophic habits for all size range and sexes (males, females, and ovigerous females). In like manner that the densities, aquatic vegetation provided with heterogeneity to development of more diversities of prey, it force to observe more stomach of the prawn due to higher of resource than those occurs in environments without, or impoverished of aquatic vegetation.

The observations for fungi, primarily ascomycetes, in the stomachs of decapods could be related to their need to ingest microorganisms capable of decomposition to make plant energy available (Zimmer \& Topp 2000). The consumption of plant material provides energy at the expense of its hard conditions and great
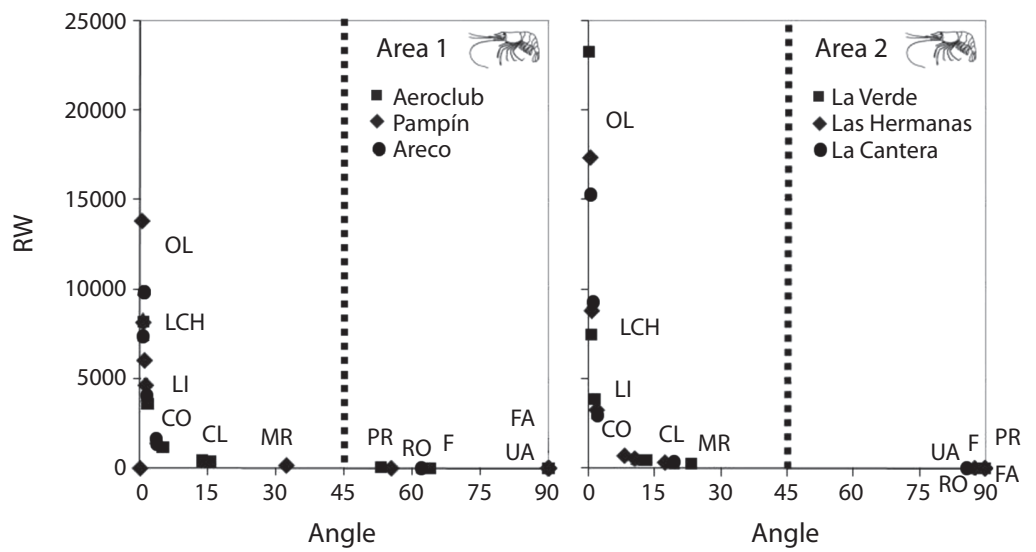

Fig. 6. Weighted Result Index (RW) of major food items that found in the stomach content of Pseudopalaemon bouvieri according to the angle of preponderance from lagoons of the area 1 and 2. MR, macrophytes remains; OL, oligochaetes; CO, copepods; CL, cladocerans; LCH, chironomidae larvae; LI, insects larvae; PR, protozoa; RO, rotifers; F, fungi; UA, unicellular algae; FA, filamentous algae. The points plotted from the midline to the left correspond to the items that making a greater contribution in volume. The points in the right side correspond to the items with greater contribution in frequency. 
quantity of produced waste. By including plants as a food source, decapods display a strategy that utilizes readily available food in the environment and eliminates the need to search for other food sources (Wolcott \& O'Connor 1992, Williner 2010). This abundant energy resource could be available immediately to the upper levels of the food web.

Macrophytes have been considered key components of habitat in aquatic environments, because of their role in structuring invertebrate assemblages (Poi de Neiff \& Neiff 2006, Thomaz et al. 2008). Conductivity was the more distinctive abiotic parameter between the areas. Our results indicated that the abundance of $P$. bouvieri varied between the study areas and among lagoons with different percentage of aquatic vegetation cover (area 1). The complexities of the vegetated zone could be inducing differences in proportions between males and females, as a mechanism of separation with the latter being more frequent in the roots of aquatic plants. The separation of the sexes during the reproductive season, e.g., spring, could be a strategy employed to avoid the competence by space and resource. The lagoons with major cover of aquatic plants had a highest proportion of ovigerous females. The preference of the females by the vegetated zone could be related to the available refuge and food, therefore allowing for a more successful reproductive season (Albertoni et al. 2003, Montoya 2003, Pelicice \& Agostinho 2006, Collins et al. 2006).

The relationship between cephalothorax length (CL) of $P$. bouvieri and conductivity could be reflected by the growth (e.g., intermolt period and/or increase by molt); however, the final size of the prawns at all lagoons observed was similar. The food should be providing the necessary nutrients to allow growth, storage, and reproduction (Karasov \& Martinez del Río 2007). While, the variation of the trophic spectrum due to conductivity was not significant at the functional level, it could be reflected at the species levels that were used as prey or food, or at the significance level according to the method used (Williner 2010). Stomach content analysis revealed no significant diet differences between juvenile and adult prawns that fed on a variety of food comprised mainly of plant remains, algae, zooplankton, oligochaeta, insect larvae and detritus. Moreover, the food resource was used in a similar manner by all sizes and sexes of $P$. bouvieri and other decapod species, e.g., Macrobrachium borellii (Nobili, 1896) (Collins \& Paggi 1998), but unlike Palaemonetes argentinus Nobili, 1901 (Collins 1999).

Furthermore, the prey of the prawns was more diverse in the lagoons of the area with more aquatic vegetation. This finding was evident from the dissection and observation of a number of prawns with large stomachs. The coefficient of variation was low for the plant remains; this item was more constant among the lagoons.

The dietary items consumed by prawns and the niche breadth were similar between the two areas, although the proportion of items consumed varied between lagoons of different areas. The density of $P$. bouvieri was different between areas and the size of cephalothorax (CL) was similar in both areas. Therefore, the hypothesis can be only partially accepted.

In the theoretical concepts, omnivores in aquatic continental systems help stabilize populations and communities by combining the resources with different conversion efficiencies (Krivan \& Diehl 2005, Walker 2009). This characteristic regulates the flow of energy and the recycling of nutrients (Evans-White et al. 2001, Buck et al. 2003, Williner 2010). Omnivory was observed in other decapods of freshwater environments in the same region, such as the prawns $M$. borellii and P. argentinus, the freshwater crab Dilocarcinus pagei (Stimpson, 1861), and the freshwater anomuran Aegla uruguayana (Schmitt, 1942) (Collins \& Paggi 1998, Collins 1999, Williner \& Collins 2002, Williner 2010). All these species live in environments with abundant organic matter mainly it come from to aquatic plants. Given the similarity of the freshwater crab species mentioned above, the importance of vegetal items remains remarkable to the prawns. 
Moreover, $P$. bouvieri consumes with a greater frequency and volume upon autotrophic organisms at area 1 than area 2, where the cover of aquatic vegetation was low. Species that possess enzymes from endosymbiotic bacteria are able to break down the cellulose of the plant remains consumed by the prawns (Karasov \& Martinez del Río 2007).

Omnivory is very common in natural communities. Low nutritional quality of the resources creates conditions for the evolution and maintenance of omnivory (Diehl 2003). However omnivory may have resulted from animals incidentally consuming animal material from the detrital compartment (Thompson et al. 2009). Gut content analysis can not distinguish these events and the use of stable isotopes is recommended for food webs structure (Woodward \& Hildrew 2002).

\section{ACKNOWLEDGMENTS}

This study was supported by PICT 01360 , Diversidad biológica en ambientes dulceacuícolas a través del gradiente este-oeste de Argentina: rotíferos, microcrustáceos y macrocrustáceos como grupos de estudio.

\section{RESUMEN}

Los crustáceos decápodos de agua dulce son un componente importante de la cadena trófica, pero poco se sabe sobre la dieta de las especies que viven en aguas tropicales. Nosotros estudiamos la ecología alimentaria del camarón Pseudopalaemon bouvieri y la estructura de su población en dos áreas diferentes con seis lagunas, con una diferente composición y abundancia de macrófitas acuáticas. En cada sitio poblado con macrófitas, se tomaron 18 muestras con una red manual (1mm de tamaño de malla) de $1 \mathrm{~m}^{2}$. En laboratorio, se midió la longitud de cefalotórax de los camarones y se determinó el sexo. Asimismo, fueron examinados un total de 208 estómagos para determinar su alimentación. Nuestros resultados mostraron que la abundancia de la población varió entre $10 \mathrm{ind} / \mathrm{m}^{2}$ y $1411 \mathrm{ind} /$ $\mathrm{m}^{2}$. La longitud de cefalotórax osciló entre 6 y $21 \mathrm{~mm}$, y la razón macho:hembra varió entre 0.3 y 1.0 , con una mayor proporción de hembras ovígeras $(21 \%)$ en el área 1 que en el área 2. P. bouvieri es omnívoro y su alimentación se basa principalmente en algas, restos de plantas, protozoos, rotíferos, Oligochaeta, crustáceos, Insecta, detrito y otros ítems. El análisis del contenido estomacal no reveló ninguna diferencia significativa en la dieta entre juveniles y adultos, y los machos y hembras de ambas áreas consumieron una dieta similar (Kruskal-Wallis, $\mathrm{p}=0.8273$ ). Nosotros concluimos que los ítems alimentarios consumidos por los camarones y la amplitud de nicho fueron similares entre las dos áreas, aunque la proporción de ítems consumidos varió entre lagunas de ambas áreas. La densidad de P. bouvieri fue diferente entre áreas, pero el tamaño del cefalotórax (CL) fue similar.

Palabras clave: ecología de la alimentación, omnívoros, proporción sexual, densidad de camarones, Crustacea.

\section{REFERENCES}

Albertoni, E.F., C. Palma-Silva \& F.A. Esteves. 2003. Overlap of dietary niche and electivity of three shrimp species (Crustacea, Decapoda) in a tropical coastal lagoon (Rio de Janeiro, Brazil). Rev. Bras. Zool. 20: 135-140.

Bond-Buckup, G. \& L. Buckup. 1989. Os Palaemonidae de águas continentais do Brasil Meridional (Crustacea, Decapoda). Rev. Bras. Biol. 49: 883-896.

Borteiro, C., F. Gutiérrez, M. Tedros \& F. Kolenc. 2009. Food habits of the Broad-snouted Caiman (Caiman latirostris: Crocodylia, Alligatoridae) in northwestern Uruguay. Stud. Neotrop. Fauna Environ. 44: 31-36.

Buck, T.L., G.A. Breed, S.C. Pennings, M.E. Chase, M. Zimmer \& T.H. Carefoot. 2003. Diet choice in an omnivorous salt-marsh crab: different food types, body size, and habitat complexity. J. Exp. Mar. Biol. Ecol. 292: 103-116.

Collins, P.A. 1995 Variaciones diarias de la actividad trófica en una población de Palaemonetes argentinus (Crustacea Decapoda). Rev. Asoc. Cienc. Nat. Litoral 26: 57-66.

Collins, P.A. 1997. Ritmo diario de alimentación del camarón Macrobrachium borellii (Decapoda: Palaemonidae). Iheringia. Sér. Zool. 82: 19-24.

Collins, P.A. 1999. Feeding of Palaemonetes argentinus (Nobili) (Decapoda: Palaemonidae) in flood valley of river Paraná, Argentina. J. Crustac. Biol. 19: 485-492.

Collins, P.A. \& J.C. Paggi. 1998. Feeding ecology of Macrobrachium borelli (Nobili) (Decapoda: Palaemonidae) in the flood valley of the River Paraná, Argentina. Hydrobiologia 362: 21-30.

Collins, P.A., F. Giri \& V. Williner. 2004. Crustáceos Decápodos del Litoral Fluvial Argentino. (Crustacea: Eucarida). INSUGEO. Miscelánea 12: 253-264. 
Collins, P.A., F. Giri \& V. Williner. 2006. Population dynamics of Trichodactylus borellianus (Crustacea. Decapoda. Brachyura) and interactions with the aquatic vegetation of the Paraná River (South America, Argentina). Ann. Limnol. Int. J. Lim. 42: 19-25.

Collins, P.A., V. Williner \& F. Giri. 2007. Littoral Communities. Macrocrustaceans, p. 277-301. In M.H. Iriondo, J.C. Paggi \& M.J. Parma (eds.). The Middle Paraná River. Limnology of a Subtropical Wetland. Springer, Berlin, Heidelberg, Germany.

Colwell, R.K. 2006. EstimateS: Statistical estimation of species richness and shared species from samples. Version 8 (Downloaded: January 21, 2010, http:// www.purl.oclc.org/estimates).

Diehl, S. 2003. The evolution and maintenance of omnivory: dynamic constraints and the role of food quality. Ecology 84: 2557-2567.

Dumont, H.J., I. Van de Velde \& S. Dumont. 1975. The dry weight estimate of biomass in a selection of Cladocera, Copepoda and Rotifera from the plankton, periphyton and benthos of continental waters. Oecologia 19: 79-97.

Edmonson, W.F. \& G.G. Winberg. 1971. A Manual on Methods for the Assessment of Secondary Productivity in Fresh Waters, Blackwell Scientific Publications, Oxford, England.

Evans-White, M., W.K. Dodds, L.A. Gray \& K.M. Fritz. 2001. A comparison of the trophic ecology of the crayfishes (Orconectes nais (Faxon) and Orconectes neglectus (Faxon)) and the central stoneroller minnow (Campostoma anomalum (Rafinesque)): omnivory in a tallgrass prairie stream. Hydrobiologia 462: 131-144.

Fernández, H.R. \& E. Domínguez. 2001. Guía para la determinación de los artrópodos bentónicos sudamericanos. Universidad Nacional de Tucumán. Facultad de Ciencias Naturales e Instituto M. Lillo, Tucumán, Argentina.

Howard, R.K. 1984. The trophic ecology of caridean shrimps in an eelgrass community. Aquat. Bot. 18: 155-174.

Jayachandran, K.V. 2001. Palaemonid prawns: biodiversity, taxonomy, biology and management. Science, Enfield, New Hampshire, USA.

Karasov, W.H. \& C. Martinez del Rio. 2007. Physiological Ecology: How Animals Process Energy, Nutrients, and Toxins, Princeton University, Princeton, USA.
Krivan, V. \& S. Diehl. 2005. Adaptative omnivory and species coexistence in tri-trophic food webs. Theor. Popul. Biol. 67: 85-99.

Lopretto, E.C. 1995. Crustacea Eumalacostraca, p. 10011039. In E.C. Lopretto \& G. Tell (eds.). Ecosistemas de aguas continentales, Ediciones Sur, La Plata, Argentina.

Lopretto, E.C. \& G. Tell. 1995. Ecosistemas de Aguas Continentales, Metodología para su Estudio. Ediciones Sur, La Plata, Argentina.

Masitah, I. \& V.C. Chong. 2002. Population and Feeding Ecology of Parapenaeopsis scuiptilis (Heller, 1862) in Klang Strait, Peninsular Malaysia. Malaysian J. Science 21: 61-68.

Mohan, M.V. \& T.M. Sankaran. 1988. Two new indices for stomach content analysis of fishes. J. Fish. Biol. 33: 289-292.

Montoya, J.V. 2003. Freshwater shrimps of the genus Macrobrachium associated with roots of Eichhornia crassipes (water hyacinth) in the Orinoco Delta (Venezuela). Caribb. J. Sci. 39: 155-159.

Pelicice, F.M. \& A.A. Agostinho. 2006. Feeding ecology of fishes associated with Egeria spp. patches in a tropical reservoir, Brazil. Ecol. Freshw. Fish. 15: 10-19.

Pianka, E.R. 1973. The structure of lizard communities. Annu. Rev. Ecol. Syst. 4: 53-74.

Pinkas, L., M.S. Oliphant \& I.L.K. Iverson. 1971. Food habits of albacore, bluefin tuna and bonito in California waters. Fish. Bull. Calif. Dep. Fish. Game 152: 1-105.

Poi de Neiff, A. 2003. Invertebrados de la vegetación del Iberá, p. 171-191. In A. Poi de Neiff (ed.). Limnología del Iberá. Aspectos físicos, químicos y biológicos de sus aguas, Editorial Universitaria de la Universidad Nacional del Nordeste (Eudene), Corrientes, Argentina.

Poi de Neiff, A. \& J.J. Neiff. 2006. Riqueza de especies y similaridad de los invertebrados que viven en plantas flotantes de la planicie de inundación del río Paraná. Interciencia 31: 220-225.

Ricklefs, R. 1979. Ecology. Chiron, University of Pennsylvania, New York, USA.

Rosemond, A.D., C.M. Pringle \& A. Ramírez. 1998. Macroconsumer effects on insect detritivores and detritus processing in a tropical stream. Freshwater Biol. 39: 515-523. 
Ruttner-Kolisko, A. 1977. Suggestions for biomass calculation of plankton rotifers. Arch. Hydrobiol. 8: 71-76.

Thomaz, S.M., E.D. Dibble, L.R Evangelista, J. Higuti \& L.M. Bini. 2008. Influence of aquatic macrophyte habitat complexity on invertebrate abundance and richness in tropical lagoons. Freshwater Biol. 53: 358-367.

Thompson, R., M. Hemberg, B.M. Starzomski \& J. Shurin. 2009. The ubiquity of omnivory. Verh. Internat. Verein. Limnol. 30: 761-764.

Walker, I. 2009. Omnivory and resource-sharing in nutrient-deficient Rio Negro waters: Stabilization of biodiversity? Acta Amazon. 39: 617-626.

Williner, V. \& P.A. Collins. 2002. Daily rhythm of feeding activity of a freshwater crab Dilocarcinus pagei pagei in National Park Río Pilcomayo, Formosa, Argentina, p. 171-178. In E. Escobar-Briones \& F. Alvarez (eds.). Modern approaches to the study of Crustacea. Kluwer Academic and Plenum Publishers, New York, USA.
Williner, V. 2010. Foregut ossicles morphology and feeding of the freshwater anomuran crab Aegla uruguayana (Decapoda, Aeglidae). Acta Zool. 91: 408-415.

Wolcott, D.L. \& N.J. O'Connor. 1992. Herbivory in crabs: adaptations and ecological considerations. Am. Zool. 32: $370-381$.

Woodward, G. \& A.G. Hildrew. 2002. Food web structure in riverine landscapes. Freshwater Biol. 47: 777-798.

Zalocar de Domitrovic, Y. 2003. Fitoplancton de lagunas y cursos de agua del Sistema Iberá, p. 85-142. In A. Poi de Neiff (ed.). Limnología del Iberá. Aspectos físicos, químicos y biológicos de sus aguas, Editorial Universitaria de la Universidad Nacional del Nordeste (Eudene), Corrientes, Argentina.

Zar, J.H. 1996. Biostatistical Analysis. Prentice Hall, New Jersey, USA.

Zimmer, M. \& W. Topp. 2000. Species-specific utilization of food sources by sympatric woodlice (Isopoda: Oniscidea). J. Anim. Ecol. 69: 1071-1082. 